\title{
PERAN PEMBELAJARAN BERBASIS MASALAH UNTUK MENINGKATKAN KEMAMPUAN KOMUNIKASI DAN BERPIKIR KREATIF SERTA DISPOSISI MATEMATIS SISWA SMA
}

Oleh:

\author{
Dedeh Tresnawati Choridah \\ Guru SMA Negeri 2 Cimahi \\ dedeh.tresnawati@yahoo.com
}

\begin{abstract}
Kemampuan komunikasi, berpikir kreatif dan disposisi matematis merupakan kemampuan yang sangat penting dimiliki oleh setiap siswa dalam pembelajaran matematika. Untuk meningkatkan kemampuan ini, perlu adanya upaya pendekatan pembelajaran yang memungkinkan siswa melakukan observasi dan eksplorasi agar dapat membangun pengetahuannya sendiri. Pembelajaran berbasis masalah merupakan salah satu alternatif pembelajaran yang dapat diterapkan di kelas untuk meningkatkan kemampuan tersebut. Dalam pembelajaran ini siswa dituntut berkomunikasi dan kreatif dalam mengemukakan idenya.
\end{abstract}

Kata Kunci : komunikasi matematis, berpikir kreatif, disposisi matematik, pembelajaran berbasis masalah.

Communication skills, creative thinking and mathematical disposition is a very important capability of every student in the learning of mathematics. To improve this ability, should the effort approach to learning that allows students to make observations and exploration in order to construct their own knowledge. Problem-based learning is one alternative learning that can be applied in the classroom to enhance the capabilities. In this lesson students are required to communicate and creative in expressing his ideas.

mathematical communication, creative thinking, mathematical disposition and problembased learning

Key words : mathematical communication, creative thinking, mathematical disposition, problem-based learning

\section{Latar Belakang Masalah}

Pendidikan merupakan suatu usaha manusia untuk menuju ke arah hidup yang lebih baik. Hal ini sesuai dengan Undang-Undang Nomor 20 Tahun 2003 tentang Sistem Pendidikan Nasional, Pasal 1 ayat 1 menyatakan bahwa pendidikan adalah usaha sadar dan terencana untuk mewujudkan suasana belajar dan proses pembelajaran agar peserta didik secara aktif mengembangkan potensi dirinya untuk memiliki kekuatan spiritual keagamaan, pengendalian diri, kepribadian, kecerdasan, akhlak mulia, serta keterampilan yang diperlukan dirinya, masyarakat, bangsa dan negara. 
Kurikulum Tingkat Satuan Pendidikan (KTSP) pada Peraturan Menteri Pendidikan Nasional Nomor 22 tahun 2006 tentang Standar Isi, menyatakan mata pelajaran matematika untuk semua jenjang pendidikan dasar dan menengah bertujuan agar siswa mampu:

1. Memahami konsep matematika, menjelaskan keterkaitan antar konsep dan mengaplikasikan konsep atau algoritma, secara luwes, akurat, efisien, dan tepat dalam pemecahan masalah,

2. Menggunakan penalaran pada pola dan sifat, melakukan manipulasi matematika dalam membuat generalisasi, menyusun bukti, atau menjelaskan gagasan dan pernyataan matematika,

3. Memecahkan masalah yang meliputi kemampuan memahami masalah, merancang model matematika, menyelesaikan model, dan menafsirkan solusi yang diperoleh,

4. Mengkomunikasikan gagasan dengan simbol, tabel, diagram, atau media lain untuk memperjelas keadaan atau masalah,

5. Memiliki sikap menghargai kegunaan matematika dalam kehidupan, yaitu memiliki rasa ingin tahu, perhatian, dan minat dalam mempelajari matematika, serta sikap ulet dan percaya diri dalam pemecahan masalah.

Tujuan mata pelajaran matematika tersebut masih jauh dari kenyataan. Sampai dengan saat ini belum ada data atau fakta yang dapat dijadikan bukti bahwa hasil pembelajaran matematika di Indonesia sudah berhasil baik. Berdasarkan laporan Trends in International Mathematics and Science Study (TIMSS) tahun 2011, Indonesia berada pada peringkat ke-38 dari 42 negara peserta, dengan skor 386 dibawah skor rata-rata 500. Skor Indonesia ini turun 11 poin dari penilaian tahun 2007. Hal ini merupakan indikator yang menunjukkan bahwa hasil pembelajaran matematika di Indonesia belum memperlihatkan hasil yang memuaskan.

Senada dengan laporan tersebut, PISA (Program for International Student Assessment) 2009 dalam kemampuan membaca, matematika dan iptek secara keseluruhan, posisi Indonesia berada pada peringkat 57 dari 65 negara. Skor tertinggi diraih Kota Shanghai, China kemampuan matematikanya mencapai skor 600 sedangkan skor Indonesia adalah 371. Ini berarti Indonesia berada pada level rendah dalam kemampuan matematika.

Dalam Standar Kompetensi Lulusan Kurikulum 2013 dikemukakan kriteria mengenai kualifikasi kemampuan lulusan dalam matematika, yang mencakup sikap, pengetahuan, dan keterampilan yaitu :

1. Sikap

Memiliki perilaku yang mencerminkan sikap orang beriman, berakhlak mulia, berilmu, percaya diri, dan bertanggung jawab dalam berinteraksi secara efektif dengan lingkungan sosial dan alam serta dalam menempatkan diri sebagai cerminan bangsa dalam pergaulan dunia. 
2. Pengetahuan

Memiliki pengetahuan faktual, konseptual, prosedural, dan metakognitif dalam ilmu pengetahuan, teknologi, seni, dan budaya dengan wawasan kemanusiaan, kebangsaan, kenegaraan, dan peradaban terkait penyebab serta dampak fenomena dan kejadian.

\section{Keterampilan}

Memiliki kemampuan pikir dan tindak yang efektif dan kreatif dalam ranah abstrak dan konkret sebagai pengembangan dari yang dipelajari di sekolah secara mandiri.

Sesuai dengan SKL Kurikulum 2013 di atas, pada pembelajaran matematika siswa tidak sekedar belajar pengetahuan kognitif, namun dia diharapkan memiliki sikap kritis dan cermat, obyektif dan terbuka, menghargai keindahan matematika, serta rasa ingin tahu, berpikir dan bertindak kreatif, serta senang belajar matematika. Sikap dan kebiasaan berpikir seperti itu pada hakekatnya akan membentuk dan menumbuhkan disposisi matematik (mathematical disposition) yaitu keinginan, kesadaran dan dedikasi yang kuat pada diri siswa untuk belajar matematika dan melaksanakan berbagai kegiatan matematika (Sumarmo,2013:55).

Untuk dapat mencapai standar-standar pembelajaran itu, seorang guru hendaknya dapat menciptakan suasana belajar yang memungkinkan bagi siswa untuk secara aktif belajar dengan mengkonstruksi, menemukan dan mengembangkan pengetahuannya. Dengan belajar matematika diharapkan siswa mampu menyelesaikan masalah, menemukan dan mengkomunikasikan ide-ide yang muncul dalam benak siswa.

Di antara berbagai pendekatan pembelajaran yang mampu mengembangkan kemampuan komunikasi, berpikir kreatif dan disposisi matematik adalah pendekatan Pembelajaran berbasis masalah (Problem Based Learning). Hal ini sesuai dengan hasil penelitian yang dilakukan Sugandi (2010) tentang PBL yang mampu meningkatkan kemampuan berpikir matematis tingkat tinggi siswa SMA.

\section{Kajian Teori}

\section{Komunikasi Matematik (Mathematical Communication)}

Kemampuan komunikasi merupakan kemampuan berpikir tingkat tinggi yang penting ditumbuhkembangkan. Pentingnya komunikasi matematik dikembangkan dalam pembelajaran matematika seiring dengan hasil survey yang dilakukan oleh Program for International Student Asesment (PISA) tahun 2009 dalam kemampuan membaca, matematika dan iptek secara keseluruhan, posisi Indonesia berada pada peringkat 57 dari 65 negara peserta untuk bidang Matematika. Survey yang dilakukan PISA menilai kemampuan matematika siswa dalam memecahkan 
masalah, yang meliputi mengenali dan menganalisis masalah, memformulasikan alasan dan mengkomunikasikan gagasan yang dimilikinya kepada orang lain.

Matematika merupakan suatu bahasa. Matematika sebagai suatu bahasa tentunya sangat diperlukan untuk dikomunikasikan baik secara lisan maupun tulisan sehingga informasi yang disampaikan dapat diketahui dan dipahami oleh orang lain. Seperti apa yang dikemukakan Cockroft (Shadiq, 2004: 19), 'We believe that all these percepcions of the usefulness of mathematics arise from the fact that mathematics provides a means of communication which is powerful, concise, and unambiguous.' Pernyataan ini menunjukkan tentang perlunya para siswa belajar matematika dengan alasan bahwa matematika merupakan alat komunikasi yang sangat kuat, teliti, dan tidak membingungkan.

Kemampuan komunikasi sangat perlu dihadirkan secara intensif agar siswa terlibat aktif dalam pembelajaran dan menghilangkan kesan bahwa matematika merupakan pelajaran yang asing dan menakutkan. Kemampuan komunikasi matematik juga sangat penting karena matematika pada dasamya adalah bahasa yang syarat dengan notasi dan istilah hingga konsep yang terbentuk dan dipahami serta dimanipulasi oleh siswa. Menurut Barody (Yonandi, 2010) ada dua alasan mengapa komunikasi matematik penting, yaitu: (1) mathematics as language, maksudnya adalah matematika tidak hanya sekedar alat bantu berpikir. Matematika membantu untuk menemukan pola, menyelesaikan masalah, akan tetapi matematika juga an invaluable for communicating a variety of ideas, precisely, and succinctly dan (2) mathematics is learning as social activity, maksudnya adalah sebagai aktivitas sosial dalam pembelajaran matematika, seperti halnya interaksi antar siswa, komunikasi guru dengan siswa, komunikasi guru dengan siswa merupakan bagian penting pada pembelajaran matemtika dalam upaya membimbing siswa memahami konsep atau mencari solusi suatu masalah.

Kemampuan Komunikasi Matematik tercantum dalam kurikulum matematika sekolah menengah (NCTM, 2000). Komponen tujuan pembelajaran matematika antara lain : dapat mengomunikasikan gagasan dengan simbol, tabel, diagram atau ekspresi matematik untuk memperjelas keadaan atau masalah, dan memiliki sikap menghargai kegunaan matematika dalam kehidupan, sikap rasa ingin tahu, perhatian, dan minat dalam mempelajari matematika, serta sikap ulet dan percaya diri dalam pemecahan masalah.

Sumarmo (Sumarmo,2013:20) mengidentifikasi indikator komunikasi matematik yang meliputi kemampuan :

a. Menghubungkan benda nyata, gambar, dan diagram ke dalam ide matematika

b. Menjelaskan ide, situasi, dan relasi matematik, secara lisan dan tulisan dengan benda nyata, gambar, grafik dan aljabar.

c. Menyatakan peristiwa sehari-hari dalam bahasa atau simbol matematika.

d. Mendengarkan, berdiskusi, dan menulis tentang matematika. 
e. Membaca dengan pemahaman suatu presentasi matematika.

f. Menyusun konjektur, menyusun argument, merumuskan definisi dan generalisasi.

g. Mengungkapkan kembali suatu uraian atau paragraf matematika dalam bahasa sendiri.

Berikut contoh soal trigonometri yang menguji kemampuan komunikasi siswa :

Sebuah kapal berlayar dari pelabuhan dengan arah $135^{\circ}$. Kecepatan rata-rata $\mathrm{v}$ $\mathrm{km} / \mathrm{jam}$. Setelah bergerak selama 6 jam kapal harus berputar arah menjadi $225^{\circ}$ selama 8 jam menuju kota A.

a. Nyatakan situasi tersebut dalam bentuk yang mudah dipahami.

b. Bagaimana cara menentukan jarak pelabuhan dengan kota A sekarang. Jelaskan.

\section{Berpikir Kreatif Matematik}

Sekolah adalah salah satu tempat dimana peserta didik menimba ilmu pengetahuan, mengembangkan bakat-bakat dan keterampilan yang dimilikinya, dan tempat untuk menuangkan ide-ide cemerlang sebagai bagian dari proses berpikir kreatif. Berpikir kreatif sangat penting dikembangkan agar siswa bisa menjadi orang bermanfaat bagi dirinya dan juga orang lain, Ruseffendi (1991: 238) mengatakan bahwa manusia kreatif itu tidak hanya baik bagi dirinya sendiri tetapi juga berfaedah bagi orang lain.

Untuk membuat siswa berpikir kreatif tidaklah mudah perlu upaya dan kerja keras yang serius dari para Guru. Kemampuan berpikir kreatif perlu dilatih sejak dini melalui pembiasaan secara konsisten. Hal ini ditegaskan oleh Ruseffendi (1991: 239) bahwa sifat kreatif akan tumbuh pada diri anak bila ia dilatih, dibiasakan sejak kecil untuk melakukan eksplorasi, inkuiri, penemuan, dan pemecahan masalah.

Selanjutnya, Munandar (Sumarmo, 2013:481) merinci ciri-ciri keempat komponen berpikir kreatif sebagai proses sebagai berikut,

Ciri-ciri fluency meliputi :

1. Mencetuskan banyak ide, banyak jawaban, banyak penyelesaian masalah, banyak pertanyaan dengan lancar .

2. Memberikan banyak cara atau saran untuk melakukan berbagai hal.

3. Selalu memikirkan lebih dari satu jawaban.

Ciri-ciri flexibility diantaranya adalah :

1. Menghasilkan gagasan, jawaban, atau pertanyaan yang bervariasi, dapat melihat suatu masalah dari sudut pandang yang berbeda-beda.

2. Mencari banyak alternatif atau arah yang berbeda-beda.

3. Mampu mengubah cara pendekatan atau cara pemikiran. 
Ciri-ciri originality diantaranya adalah :

1. Mampu melahirkan ungkapan yang baru dan unik.

2. Memikirkan cara yang tidak lazim untuk mengungkapkan diri.

3. Mampu membuat kombinasi-kombinasi yang tidak lazim dari bagian-bagian atau unsur-unsur.

Ciri-ciri elaboration diantaranya adalah :

1. Mampu memperkaya dan mengembangkan suatu gagasan atau produk

2. Menambah atau memperinci detil-detil dari suatu obyek, gagasan atau situasi sehingga menjadi lebih menarik.

Berikut adalah contoh soal trigonometri yang mengukur kemampuan berpikir kreatif matematik ;

Alya mengamati sebuah perlomban perahu layar dari puncak sebuah mercusuar setinggi 80 meter. Dia sedang mengamati 2 perahu layar milik Dodi dan Coki yang segaris dengan kaki menara pada sudut $30^{\circ}$ dan $60^{\circ}$. Tepat di tempat Alya berada berdiri tegak sebuah tiang bendera yang titik ujungnya terlihat oleh Dodi dengan sudut elevasi tertentu.

a. Tentukan beberapa cara untuk menentukan jarak antara posisi Dodi dan Coki pada saat itu.

b. Cukupkah informasi di atas untuk menghitung panjang dari tiang bendera tersebut? Jika ya hitunglah panjangnya. Jika tidak, tambahkan informasi baru kemudian hitung panjangnya!

\section{Disposisi Matematik}

Menurut NCTM (2000) disposisi matematika mencakup beberapa komponen sebagai berikut :

1. Percaya diri dalam menggunakan matematika untuk menyelesaikan masalah, mengkomunikasikan ide-ide matematis dan memberikan argumentasi

2. Berpikir fleksibel dalam mengeksplorasi ide-ide matematis dan mencoba metode alternatif dalam menyelesaikan masalah

3. Gigih dalam mengerjakan tugas matematika

4. Berminat, memiliki keingintahuan (coriousity)dan memiliki daya cipta (inventiveness) dalam aktivitas bermatematika

5. Memonitor dan merefleksi pemikiran dan kinerja

6. Menghargai aplikasi matematika pada disiplin ilmu lain atau dalam kehidupan sehari-hari

7. Mengapresiasi peran matematika sebagai alat dan sebagai bahasa

Disposisi merupakan karakter atau kepribadian yang diperlukan seorang individu untuk sukses. Siswa memerlukan disposisi matematis untuk bertahan dalam menghadapi masalah, mengambil tanggung jawab dalam belajar mereka dan mengembankan kebiasaan kerja yang baik dalam matematika. Karakeristik demikian 
penting dikembangkan dan dimiliki siswa. Kelak siswa belum tentu akan meggunakan semua materi yang mereka pelajari di sekolah. Tetapi dapat dipastikan bahwa mereka memerlukan disposisi positif untuk menghadapi situasi problematik dalam kehidupan mereka.

Dalam 10 standar NCTM (2000) dikemukakan bahwa disposisi matematik meunjukkan rasa percaya diri, ekspektasi dan metakognisi, perhatian serius dalam belajar matematika, kegigihan dalam menghadapi dan menyelesaikan masalah, rasa ingin tahu yang tinggi serta kemampuan berbagi pendapat dengan orang lain. Selanjutnya NCTM (2000) menyatakan bahwa sikap siswa dalam menghadapi matematika dan keyakinannya dapat mempengaruhi prestasi mereka dalam matematika.

Sikap siswa terhadap matematika tidak dapat dipisahkan dari kemampuan matematis siswa. Siswa yang memiliki kemampuan lemah cenderung akan bersikap negatif terhadap matematika, sebaliknya siswa yang memiliki kemampuan matematika yang baik cenderung akan bersikap positif terhadap matematika. Namun dapat pula terjadi sebaliknya, siswa yang bersikap negatif terhadap matematika akan cenderung memiliki kemampuan matematika yang lemah, sedangkan siswa yang bersikap positif terhadap matematika akan cenderung makin memiliki kernampuan yang baik pula.

\section{Pembahasan}

Pembelajaran berbasis masalah menurut Arend (Asikin, 2001) adalah model pembelajaran dengan pendekatan pembelajaran siswa pada masalah autentik sehingga siswa dapat menyusun pengetahuannya sendiri, menumbuhkembangkan ketrampilan berpikir tingkat tinggi dan inkuiri, memandirikan siswa dan meningkatkan kepercayaan sendiri. Adapun langkah-langkah yang ditempuh dalam pembelajaran berbasis masalah adalah :

a. Orientasi siswa pada masalah

b. Mengorganisir siswa dalam belajar

c. Membimbing penyelidikan individual maupun kelompok

d. Mengembangkan dan menyajikan hasil karya

e. Menganalisis dan mengevaluasi proses pemecahan masalah

Strategi pembelajaran berbasis masalah memiliki karakteristik sebagai berikut :

a. Belajar dimulai dengan suatu permasalahan.

b. Permasalahan yang diberikan harus berhubungan dengan dunia nyata siswa.

c. Mengorganisasikan pembelajaran di seputar permasalahan, bukan di seputar disiplin ilmu.

d. Memberikan tanggung jawab yang besar dalam membentuk dan menjalankan secara langsung proses belajar mereka sendiri. 
e. Menggunakan kelompok kecil.

f. Menuntut siswa utuk mendemonstrasikan apa yang telah dipelajarinya dalam bentuk produk dan kinerja.

Berbagai penelitian tentang pembelajaran berbasis masalah mengisyaratkan keunggulannya. Menurut Herman (2006) pembelajaran berbasis masalah menyajikan masalah terbuka melalui penggunaan media pembelajaran interaktif berpengaruh secara signifikan pada peningkatan kemampuan matematis siswa . Pembelajaran berbasis masalah merupakan pembelajaran kooperatif dimana siswa akan lebih mudah menemukan dan memahami konsep-konsep yang sulit apabila mereka dapat saling mendiskusikan masalah-masalah tersebut dengan temantemannya. Guru memberikan kesempatan kepada siswa untuk mengeluarkan pendapatnya sendiri, mendengar pendapat temannya, dan bersama-sama membahas permasalahan yang diberikan guru. Dengan pembelajaran kooperatif ini diharapkan akan memberikan kontribusi terhadap kemampuan komunikasi dan kreatifitas dalam pemecahan masalah matematika.

Sejalan dengan penelitian diatas, Sugandi (2010) menyimpulkan Pembelajaran Berbasis Masalah mampu meningkatkan kemampuan berpikir matematis tingkat tinggi dan kemandirian belajar siswa SMA. Pada saat diberikan masalah matematika siswa dituntut untuk memahami, bernalar dan kreatif dalam pemecahan masalah matematis, Pada saat berdiskusi dan presentasi, siswa dituntut untuk berkomunikasi, mengemukakan ide kreatifnya dengan teman dan guru.

\section{Kesimpulan}

Dalam beberapa penelitian pendidikan terbukti pembelajaran berbasis masalah dapat meningkatkan kemampuan berpikir matematis tingkat tinggi siswa. Dalam langkah pembelajaran yang melibatkan kelompok siswa dipacu untuk berkomunikasi dengan temannya. Demikian pula pada saat mempresentasikan hasil kelompok siswa dituntut untuk berkomunikasi dengan teman dan guru. Sedangkan kreatifitas siswa dituntut pada saat siswa menyelesaikan lembar kerja siswa.

Dengan membiasakan pembelajaran berbasis masalah diharapkan siswa percaya diri, gigih, berpikir fleksibel dalam mengeksplorasi ide-ide matematis, dan senang belajar matematika sehingga meningkat disposisi matematisnya.

\section{DAFTAR PUSTAKA}

Asikin, M. (2001). Komunikasi Matematika dalam RME. Makalah. Yogyakarta: Seminar Nasional RME di Universitas Sanata Dharma.

Badan Standar Nasional Pendidikan (2006). Panduan Penyusunan Kurikulum Tingkat Satuan Pendidikan (KTSP), Jakarta: BNSP. 
Depdiknas (2006). Permendiknas Nomor 22 Tahun 2006 Tentang Standar Isi Sekolah Menengah Atas, Jakarta.

Herman, T. (2006). Pengembangan Pembelajaran Matematika Berbasis Masalah untuk Meningkatkan Kemampuan Berpikir Kristis dan Kreatif Siswa SMP. Laporan Penelitian Hibah Bersaing. Tidak Diterbitkan.

Peraturan Menteri Pendidikan Dan Kebudayaan Nomor 54 Tahun 2013 (2013). Standar Kompetensi Lulusan Pendidikan Dasar Dan Menengah, Jakarta.

Mullis IVS, Martin MO, Foy, Arora A (2011). TIMSS 2011 International Results in Mathematics : Lynch School of Education, Boston College Chestnut Hill, MA, USA.

NCTM (National Council of Teachers of Mathematics) (2000), Principles and Standards for School Mathematics. Reston, Virginia: NCTM

Ruseffendi, E. T. (1991). Pengantar Kepada Membantu Guru Mengembangkan Kompetensinya dalam Pengajaran Matematika untuk Meningkatkan CBSA. Bandung: Tarsito

Shadiq,F (2009). Kemahiran Matematika : PPPPTK Matematika, Jogjakarta.

Sugandi,A.I (2010). Pengaruh Pembelajaran Berbasis Masalah dengan Setting Kooperatif Tipe Jigsaw terhadap Pencapaian Kemampuan Berpikir Matematis Tingkat Tinggi dan Kemandirian Belajar Siswa SMA di Kodya Bandung. Laporan Penelitian IKIP Bandung: Tidak diterbitkan.

Sumarmo,U. (2013), Berpikir dan Disposisi Matematik serta Pembelajarannya. Bandung: Jurdik Matematika FPMIPA UPI.

Sumarmo,U. (2013), Evaluasi dalam Pembelajaran Matematika. Bahan ajar perkuliahan Evaluasi dalam Pembelajaran Matematika Program S2 Pendidikan Matematika STKIP SILIWANGI: Tidak diterbitkan.

Yonandi (2010). Meningkatkan Kemampuan Komunikasi dan Pemecahan Masalah Matematik melalui Pembelajaran Kontekstual Berbantuan Komputer pada Siswa Sekolah Menengah Atas. Disertasi pada PPs UPI, tidak dipublikasikan. 